\section{Effects of moringa leaves (Moringa oleifera) extraction on quality changes and melanosis of giant freshwater prawn (Macrobrachium rosen- bergii) during chilled storage}

\author{
Nurul U. Karim ${ }^{1,2}$ \\ Uzmaa S.A.A. Siddiq, ${ }^{3}$ \\ Mohd R.M. Razak, ${ }^{3}$ \\ Mohamad K.M. Zainol, ${ }^{2}$ \\ Mohd I. Abdullah ${ }^{2}$ \\ ${ }^{1}$ School of Fisheries and Aquaculture \\ Sciences, ${ }^{2}$ Institute of Tropical \\ Aquaculture, ${ }^{3}$ School of Food Science \\ and Technology, Universiti Malaysia \\ Terengganu, Malaysia
}

\begin{abstract}
An aqueous extraction of moringa (Moringa oleifera) leaves were prepared as the edible coats for keeping the quality of the giant freshwater prawn (Macrobrachium rosenbergii). In addition, the antioxidant properties and activity; total phenolic content (TPC), total flavonoid contents (TFC), free radical scavenging activity (DPPH), and ferric reducing antioxidant power (FRAP) of moringa leaves were also determined. The phenolic compounds and antioxidant properties in the moringa leaves are low; 16.14 $\mathrm{mgGAEg}^{-1}$ for TPC; $5.57 \mathrm{mgQEg}^{-1}$ for TFC; $1.36 \mathrm{mgTEg}^{-1}$ for DPPH; and $3.05 \mathrm{mgTEg}^{-1}$ for FRAP. The experiment was further conducted by coating the $M$. rosenbergii with moringa leaves extraction before chilled storage at $4^{\circ} \mathrm{C}$ for 15 days. Moringa leaves extraction were effectively reduced the microflora count in $M$. rosenbergii $(\mathrm{P}<0.05)$. Total volatile basis nitrogen (TVB-N) value showed a significant $(\mathrm{P}<0.05)$ lower amount in treated samples compared to the controls. Melanosis were obvious in controls compared to the treated samples. After 15 days of chilled storage, the sensory properties; taste, texture and odour of treated samples were acceptable by the panelists. Biopreservation of moringa leaves extraction significantly benefits in keeping the quality of $M$. rosenbergii.
\end{abstract}

\section{Introduction}

Giant freshwater prawn, Macrobrachium rosenbergii is native species to the Southeast Asia, northern Australia and Indo-Pacific region that had a great demand in national and international market (Reddy and Reddy, 2014). It is notable in market due to its culinary characteristics and the unique taste of their meat (FAO, 2014a). However, the qualities of $M$. rosenbergii easily to deteriorate due to bacteria and chemical action (Ali et al., 2010) and activity of digestive enzymes (Kirschnik et al., 2006). It is probably due to collagenolytic activity caused by the disintegration of the hepatopancreas (Lindner et al., 1988). The speed of this activity is related to storage temperature (New et al., 2010). In addition, the quality deterioration also associated with inappropriate post-harvest handling and preservation (Madrid and Phillips, 2000; Kirschnik et al., 2006).

Preservation is an important process for quality assurance in seafood industry. Natural products and their secondary metabolites are commonly used as antimicrobial and antioxidant biopreservatives (Anastasio et al., 2014; Palmieri et al., 2016; Mogosanu et al., 2017). Previous studies by Ratshilivha et al., (2014) documented that the leaves extraction of Moringa oleifera able to fight against bacterial infection and can act as a source of antioxidant (Khalafalla et al., 2010). Moringa leaves contains unique nutritional qualities where it contains protein, vitamin $\mathrm{A}$ and $\mathrm{C}$, also one of the well sources of minerals such as calcium, iron, manganese and copper (Rudrappa, 2014). Leaf extracts of $M$. oleifera were reported to exhibit antioxidant activity in vitro and in vivo due to abundant of phenolic acids and flavonoids (Atawodi et al., 2010). Chen and Verdes (2009) stated that M. oleifera is a good antimicrobial agent. Viera et al. (2010) emphasized that the extract of $M$. oleifera can act against Bacillus subtilis, Staphylococcus aureus and Vibrio cholera.

Therefore, this study is to investigate the effectiveness of the moringa leaves extraction on the quality changes and melanosis of giant freshwater prawn during 15 days of chilled storage. This study also reveals the antioxidant properties and the antibacterial activity of the moringa leaves extraction. These biopreservation technique may offers as a new alternative in preservation techniques, extended shelf life and enhanced safety by using the natural resources such as moringa leaves extract.

\section{Materials and Methods}

\section{Sample collection and extraction}

Mature moringa leaves were freshly collected and cleaned before dried in oven (Ecocell EC111, Germany) at $60^{\circ} \mathrm{C}$ for 24 hours. The extraction was prepared using methods by Porwal et al. (2012).
Correspondence: Nurul Ulfah Karim, School of Fisheries and Aquaculture Sciences, Universiti Malaysia Terengganu, 21030, Kuala Terengganu, Terengganu, Malaysia. Tel.: +6096685022 - Fax: +6096685002.

E-mail: ulfah@umt.edu.my

Key words: Edible coats, quality, melanosis, Giant freshwater prawn.

Contributions: the authors contributed equally.

Conflict of interest: the authors declare no potential conflict of interest.

Funding: none.

Received for publication: 1 February 2018.

Revision received: 31 May 2018.

Accepted for publication: 6 June 2018 .

This work is licensed under a Creative Commons Attribution-NonCommercial 4.0 International License (CC BY-NC 4.0).

(C) Copyright N.U. Karim et al., 2018

Licensee PAGEPress, Italy

Italian Journal of Food Safety 2018; 7:6846 doi:10.4081/ijfs.2018.6846

Determination of antioxidant properties and activity of $M$. oleifera leave extract

Total phenolic compounds (TPC) and total flavonoid compound (TFC) were determined according to Taga et al., (1984) and Chang et al., (2002), respectively. In addition, DPPH radical-scavenging activity and ferric reducing antioxidant power (FRAP) were determined according to method by Binsan et al. (2008) and Benzie and Strain (1996). The absorbance was measured by using spectrophotometer (UV Mini-1240 UV-VIS Spectrophotometer Shimadzu, Japan) and compared to the standard calibration curve accordingly to the method.

\section{Sample preparation}

M. rosenbergii were headed, peeled and soaked in 0.5 and $1.0 \%$ moringa leaves extract for $10 \mathrm{~min}$ at $4^{\circ} \mathrm{C}$. Controls were left without coating. All samples were superchilled in blast freezer (Irinox Blast Freezer, USA) for 5 min before vacuum packed in polyethylene bags and stored at $4^{\circ} \mathrm{C}$. Analysis were done at interval of five days during 15 days of chilled storage. All experiments were done in 3 replicates.

\section{Microbiological analysis}

Total bacterial count was determined using spread plate method on plate count agar using method by Linton et al. (2003); Karim et al. (2011).10 $\pm 0.1 \mathrm{~g}$ of sample were 
homogenized with sterilized maximum recovery diluent (MRD). A serial samples dilution was prepared at appropriate dilution. Accurately, $0.1 \mathrm{~mL}$ of the dilution was spread on plate count agar (PCA) by using sterile glass spreader. All plates agar was incubated at $30^{\circ} \mathrm{C}$ for 48 hours. Plates with 30 to 300 colonies were selected and the total colonies were recorded. Total bacteria count was determined using formula:

Total bacteria per $\mathrm{mL}=$ number of colony $\mathrm{x}$ dilution factor

\section{Determination of total volatile basis nitrogen (TVB-N)}

Total volatile basis nitrogen (TVB-N) were determined using method from Karim et al. (2011). $100 \pm 0.1 \mathrm{~g}$ of prawn samples were added to $200 \mathrm{~mL}$ of $7.5 \%$ trichloroacetic acid before homogenized for 1 minute. The homogenate was centrifuged at $2000 \mathrm{~g}$ for 15 minutes and filtered through Whatman No. 1 filter paper. $25 \mathrm{~mL}$ of filtrate were pipetted into the Kjeldahl distillation tube followed by $5 \mathrm{~mL}$ of $10 \%$ sodium hydroxide. Steam-distillation were carried out using a vertical steam-distillation unit, and the distillate were collected into a beaker containing $10 \mathrm{~mL}$ of $4 \%(\mathrm{v} / \mathrm{v})$ aqueous boric acid solution and $0.04 \mathrm{~mL}$ methyl red and bromocresol green indicator up to a final volume of $50 \mathrm{~mL}$. The titration was allowed to run against aqueous $0.05 \mathrm{M}$ sulphuric acid solution and it was shaken until pink color, neutralization was indicated and persists for 15 seconds. The quantity of TVB-N in $\mathrm{mg}$ from the volume of sulphuric acid $(\mathrm{n} \mathrm{mL})$ determined as below:

$$
\text { TVB-N }(\operatorname{mgN} \text { per } 100 \mathrm{~g})=\mathrm{n} * 16.8
$$

\section{Melanosis and sensory assessment}

Giant freshwater prawn was dipped in 0.25 and $0.5 \%$ moringa extract, $1.25 \%$ sodium metabisulphate (SMS) as positive control, and distilled water as control at $4^{\circ} \mathrm{C}$ for 30 minutes. Samples were superchilled in blast freezer (Irinox Blast Freezer, USA) for $5 \mathrm{~min}$ and packed in (PE) vacuum pack (DZQ Vacuum Packer, China). Samples were kept in chilled temperature before analysed at initial and $15^{\text {th }}$ days of storage.

Melanosis assessment were done according to method by Nirmal and Benjakul (2009). Melanosis of GFP were scored through visual inspection by 30 panelists using 10 point scoring test; $0=$ absent, $2=$ slight $(20 \%$ shrimps surface affected); $4=$ moderate $(40 \%$ of shrimps surface affected); $6=$ notable $(60 \%$ of shrimps surface affected); $8=$ severe $(80 \%$ of shrimps surface affected); $10=$ extremely heavy $(100 \%$ of shrimp surface affected).

Sensory evaluation was done according to Nirmal and Benjakul (2009). All samples were placed on a stainless-steel tray covered with aluminum foil and steamed for 5 min. The cooked samples were evaluated by 30 panelists. Four-point hedonic scale were used to score the samples; $4=$ extremely like, $3=$ moderately like, $2=$ neither like nor dislike; $1=$ dislike. All panelists were asked to evaluate for taste, texture, and odor.

\section{Statistical analysis}

The entire experiment was replicated three times. The data were analyzed statistically using one-way ANOVA with post hoc Scheffe's test to compare the significant differences among groups at 0.05 level of probability. All statistical analysis were done using the IBM SPSS Statistic software (Version 20). The estimation shelf life of each treatment was fitted as the response curve with microbiology and chemical data. The microbial shelf life was taken as the time to reach $10^{7} \mathrm{CFU} \mathrm{g}^{-1}$, as recommended by International Commission on Microbiology Specification for Food (ICMSF, 1986). Meanwhile the chemical shelf life was taken as the time to reach 35 mgN $100 \mathrm{~g}^{-1}$ for TVBN (Connell and Shewan, 1980).

\section{Results and Discussion}

\section{Antioxidant properties and activity of $M$. oleifera leave extract}

Total phenolic content (TPC) and total flavonoid content (TFC) in $M$. oleifera extraction were $16.14 \pm 0.74 \mathrm{mgGAEg}^{-1}$ and $5.57 \pm 3.01 \mathrm{mgQEg}^{-1}$, respectively (Table 1). Ilyas et al. (2015) recently documented that
TPC and TFC of M. oleifera collected from Pakistan were recorded at amount of $95.35 \pm 0.60$ and $65.43 \pm 0.60 \mathrm{mgTEg}^{-1}$, respectively. Meanwhile, Iqbal and Bhanger (2006) showed the concentration of TPC and TFC; 99.50 to 111.7 and 92.40 to 98.8 $\mathrm{mgTEg}^{-1}$, respectively. A slightly lower amount of antioxidant properties was found in moringa leaves collected from South Africa. The amount of TPC were recorded at 52.50 to $74.30 \mathrm{mgTEg}^{-1}$, meanwhile the TFC were recorded at 32.60 to 108.30 mgTEg$^{-1}$ (Siddhuraju and Becker, 2003). Present studies recorded DPPH were $1.36 \pm 5.47 \mathrm{mgTEg}^{-1}$ and FRAP were $3.05 \pm 0.15 \mathrm{mgTEg}^{-1}$ (Table 1). FRAP value in $M$. oleifera collected from Pakistan showed a same range to the present studies; 0.41 to $2.68 \mathrm{mgTEg}^{-1}$ (Table 1) (Siddhuraju and Becker, 2003). The antioxidant properties and activity of $M$. oleifera of present study were low compared to previous studies (Iqbal and Bhanger, 2006; Ilyas et al., 2015). The variations of the TPC and TFC in samples could be due to the temperature and methods of extraction of polyphenolic compounds, degree of polarity of the solvents and geographical locations of the plants (Ilyas et al., 2015). The differentiation also depending on the nature of the soil and season of cultivation (Ilyas et al., 2015).

\section{Total bacterial count}

Edible coating of moringa leaves extract on $M$. rosenbergii were effectively reduced the total bacteria count $(\mathrm{P}<0.05)$ (Table 2). Coating at $1.0 \%$ of moringa leaves showed a significant $(\mathrm{P}<0.05)$ lower amount of total bacteria count compared to the samples coated with $0.5 \%$ leaves extraction. With regards to the storage, the total bacteria counts of controls were significantly $(\mathrm{P}<0.05)$ increased from $4.82 \log _{10} \mathrm{CFUg}^{-}$ ${ }^{1}$ on day 0 to $8.66 \log _{10} \mathrm{CFUg}^{-1}$ at the end of storage day (Table 2). A significantly $(\mathrm{P}<0.05)$ similar trend of total bacteria count; an increasing count parallel with the duration of storage were found in both samples treated with 0.5 and $1.0 \%$ of moringa extract (Table 2). Previous study by Onyuka et al. (2013) documented that moringa extract at $80 \mu \mathrm{gmL}^{-1}$ coated on tilapia

Table 1. Total phenolic content, total flavonoid content, radical scavenging activity and ferric reducing power of moringa leaves.

\begin{tabular}{lcccc} 
Antioxidant properties and activity & Current studies & $\begin{array}{c}\text { Ilyas et al. } \\
(2015)\end{array}$ & $\begin{array}{c}\text { Iqbal and Bhanger } \\
(2006)\end{array}$ & $\begin{array}{c}\text { Siddhuraju and Becker } \\
\text { (2003) }\end{array}$ \\
Total phenolic content $\left(\mathrm{mgGEEg}^{-1}\right)$ & $16.14 \pm 0.74$ & $95.35 \pm 0.60$ & 99.5 to 111.7 & 52.50 to 74.30 \\
Total flavonoid content $\left(\mathrm{mgEg}^{-1}\right)$ & $5.57 \pm 3.01$ & $65.43 \pm 0.60$ & 92.4 to 98.8 & 32.60 to 108.30 \\
\hline Radical scavenging activity, (DPPH) $\left(\mathrm{mgTEg}^{-1}\right)$ & $1.36 \pm 5.47$ & $0.87 \pm 0.99$ & - & 3070 \\
Ferric antioxidant reducing power, (FRAP) $\left(\mathrm{mgTEg}^{-1}\right)$ & $3.05 \pm 0.15$ & - & - & 0.41 to 2.68 \\
\hline
\end{tabular}


(Oreochromis niloticus) and silver cyprinid (Rastrineobola argentea) were effective to reduce the bacterial loads.

Onyuka et al. (2013) also confirmed that moringa extract contain antibacterial activity and can be used for fish preservation for longer time and safe for human consumption. A finding by Peixoto et al., (2011) emphasized moringa leaves has antibacterial effective against Staphylococcus aureus, Vibrio parahaemolyticus, Enterococcus faecalis and Aeromonas caviae. Viera et al. (2010) also documented that M. oleifera extract can act against Bacillus subtilis, Staphylococcus aureus and Vibrio cholera. Saadabi and Abu Zaid (2011) stated that the aqueous extract of moringa leaves were found able to inhibit pathogenic bacteria; Escherichia coli, Staphylococcus aureus, Bacillus subtilis and Pseudomonas aeroginosa. A study by Fahey (2005) stated moringa contains 4- (4'-O-acetyl-a-Lrhamnopyranosyloxy) benzyl isothiocyanate, 4-(a-L-rhamnopyranosyloxy) benzyl isothiocyanate, niazimicin, benzyl isothiocyanate, and 4- (a-L-rhamnopyranosyloxy) benzyl glucosinolate that might act as a powerful antibacterial effect.

\section{Total volatile basis nitrogen (TVB- N) value}

M. rosenbergii coated with moringa extraction showed a significant $(\mathrm{P}<0.05)$ reducing effects on the TVB-N accumulation (Table 3). A higher concentration of moringa extraction $(1.0 \%)$ showed more significantly $(\mathrm{P}<0.05)$ effective in reducing the TVB-N accumulation compared to a lower concentration $(0.5 \%)$. TVB-N value showed significantly $(\mathrm{P}<0.05)$ increasing trend during the storage period (15 days) in all samples (Table 3). After 5 day stored in chilling temperature, untreated $M$. rosenbergii started to developed mild spoilage odors. Meanwhile, M. rosenbergii coated with $0.5 \%$ of moringa extraction were at the stage of the beginning of deterioration process. However, M. rosenbergii coated with $1.0 \%$ of moringa extract only started to produce spoilage odor after $10^{\text {th }}$ day of storage period. TVB-N value were related to bacterial spoilage activity throughout the storage days (Cobb and Vanderzant, 1975) and associated with amino acid decarboxylase activity of microorganism during storage (Huss, 1995; Duman and Öspolat, 2014).

\section{Shelf life prediction}

The estimation shelf life of each treatments calculated from the response curve with curve constraints were taken as the bacteria count reach $10^{7} \mathrm{CFUg}^{-1}$ (ICMSF, 1986) and TVB-N accumulation were at 35 $\mathrm{mgN}_{100 g^{-1}}$ (Connell and Shewan, 1980). By using total bacteria count data, the shelf life of controls and samples coated at $0.5 \%$ reach of $10^{7} \mathrm{CFUg}^{-1}$ at $8^{\text {th }}$ day of storage for both treatments (Table 4). Meanwhile, samples coated with $1.0 \%$ of moringa extract, the shelf life were extended up to $9^{\text {th }}$ day by using total bacteria count data. At limit of the acceptance TVB-N value $\left(35 \mathrm{mgN} 100 \mathrm{~g}^{-1}\right)$, the shelf life of controls was at $12^{\text {th }}$ day of

Table 2. Total bacterial count $\left(\log _{10} \mathrm{CFUg}^{-1}\right)$ of Macrobrachium rosenbergii stored for 15 days in different concentration of moringa leaves extract.

\begin{tabular}{lccc} 
Storage & Control & $0.5 \%$ & $1.0 \%$ \\
Day 0 & $4.82 \pm 0.0^{\mathrm{la}, \mathrm{A}}$ & $4.65 \pm 0.05^{\mathrm{b}, \mathrm{A}}$ & $4.47 \pm 0.07^{\mathrm{c}, \mathrm{A}}$ \\
Day 5 & $6.47 \pm 0.02^{\mathrm{a}, \mathrm{B}}$ & $6.37 \pm 0.03^{\mathrm{b}, \mathrm{B}}$ & $6.32 \pm 0.02^{\mathrm{b}, \mathrm{B}}$ \\
\hline Day 10 & $7.73 \pm 0.04^{\mathrm{a}, \mathrm{C}}$ & $7.52 \pm 0.09^{\mathrm{a}, \mathrm{C}}$ & $7.23 \pm 0.12^{\mathrm{b}, \mathrm{C}}$ \\
Day 15 & $8.66 \pm 0.04^{\mathrm{a}, \mathrm{D}}$ & $8.52 \pm 0.03^{\mathrm{b}, \mathrm{D}}$ & $8.38 \pm 0.13^{\mathrm{c}, \mathrm{D}}$ \\
\hline
\end{tabular}

Different superscript $(\mathrm{a}, \mathrm{b}, \mathrm{c})$ indicate significant difference $(\mathrm{P}<0.05)$ between treatment (controls, $0.5 \%$ and $1.0 \%$ concentration). Different superscript $(A, B, C)$ indicate significant difference $(\mathrm{P}<0.05)$ between the storage days.

Table 3. Total volatile basis nitrogen value of Macrobrachium rosenbergii stored for 15 days in different concentration of moringa leaves extract.

\begin{tabular}{lccc} 
Storage & Control & $0.5 \%$ & $1.0 \%$ \\
Day 0 & $9.52 \pm 0.51^{\mathrm{a}, \mathrm{A}}$ & $6.05 \pm 0.67^{\mathrm{b}, \mathrm{A}}$ & $2.80 \pm 0.5^{\mathrm{c}, \mathrm{A}}$ \\
Day 5 & $15.68 \pm 1.94^{\mathrm{a}, \mathrm{A}}$ & $12.99 \pm 0.5^{\mathrm{a}, \mathrm{B}}$ & $9.86 \pm 0.39^{\mathrm{b}, \mathrm{B}}$ \\
\hline Day 10 & $23.41 \pm 0.20^{\mathrm{a}, \mathrm{B}}$ & $19.04 \pm 1.94^{\mathrm{b}, \mathrm{C}}$ & $16.69 \pm 0.20^{\mathrm{c}, \mathrm{C}}$ \\
Day 15 & $38.08 \pm 3.88^{\mathrm{a}, \mathrm{C}}$ & $29.90 \pm 0.58^{\mathrm{b}, \mathrm{D}}$ & $25.76 \pm 1.94^{\mathrm{b}, \mathrm{D}}$ \\
\hline
\end{tabular}

Different superscript $(\mathrm{a}, \mathrm{b}, \mathrm{c})$ indicate significant difference $(\mathrm{P}<0.05)$ between treatment (controls, $0.5 \%$ and $1.0 \%$ concentration). Different superscript $(\mathrm{A}, \mathrm{B}, \mathrm{C})$ indicate significant difference $(\mathrm{P}<0.05)$ between the storage day.

Table 4. Shelf life prediction of Macrobrachium rosenbergii stored for 15 days in different concentration of moringa leaves extract.

\begin{tabular}{|c|c|c|c|}
\hline Shelf life prediction & $\begin{array}{c}\text { Control } \\
\text { (day) }\end{array}$ & $\begin{array}{c}0.5 \% \text { prawn soaked } \\
\text { moringa extract } \\
\text { sample (day) }\end{array}$ & $\begin{array}{c}1.0 \% \text { prawn soaked } \\
\text { moringa extract } \\
\text { sample (day) }\end{array}$ \\
\hline
\end{tabular}

$\begin{array}{lccc}\text { Total bacterial count } & 8 & 8 & 9 \\ \text { Total volatile basis nitrogen } & 12 & 16 & 18\end{array}$

Total bacterial count limit for human consumption at $10^{7} \mathrm{CFUg}^{-1}$. Total volatile basis nitrogen limit for human consumption and prawn accept-

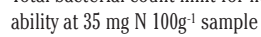

Table 5. Sensory properties of GFP treated with different treatment.

\begin{tabular}{|c|c|c|c|c|c|}
\hline Storage time, days & Treatment & Melanosis Score & Taste & Texture & Odour \\
\hline 0 & $\begin{array}{l}\text { Control } \\
1.25 \% \text { SMS } \\
0.25 \% \text { moringa extract } \\
0.5 \% \text { moringa extract }\end{array}$ & $\begin{array}{l}\text { ND } \\
\text { ND } \\
\text { ND } \\
\text { ND }\end{array}$ & $\begin{array}{l}4.00 \pm 0.00^{\mathrm{a}} \\
3.97 \pm 0.05^{\mathrm{a}} \\
3.87 \pm 0.12^{\mathrm{a}} \\
3.97 \pm 0.05^{\mathrm{a}}\end{array}$ & $\begin{array}{l}3.73 \pm 0.17^{\mathrm{a}} \\
3.90 \pm 0.08^{\mathrm{a}} \\
3.77 \pm 0.12^{\mathrm{a}} \\
3.77 \pm 0.19^{\mathrm{a}}\end{array}$ & $\begin{array}{l}3.83 \pm 0.13^{\mathrm{a}} \\
3.80 \pm 0.08^{\mathrm{a}} \\
3.80 \pm 0.08^{\mathrm{a}} \\
3.80 \pm 0.08^{\mathrm{a}}\end{array}$ \\
\hline 15 & $\begin{array}{l}\text { Control } \\
1.25 \% \text { SMS } \\
0.25 \% \text { moringa extract } \\
0.5 \% \text { moringa extract }\end{array}$ & $\begin{array}{l}10.00 \pm 0.00^{\mathrm{a}} \\
3.33 \pm 0.58^{\mathrm{b}} \\
8.67 \pm 1.53^{\mathrm{a}} \\
8.67 \pm 1.53^{\mathrm{a}}\end{array}$ & $\begin{array}{l}2.30 \pm 0.08^{\mathrm{b}} \\
3.00 \pm 0.14^{\mathrm{c}} \\
3.67 \pm 0.12^{\mathrm{d}} \\
3.53 \pm 0.05^{\mathrm{d}}\end{array}$ & $\begin{array}{l}2.40 \pm 0.08^{\mathrm{b}} \\
3.80 \pm 0.08^{\mathrm{a}} \\
3.47 \pm 0.05^{\mathrm{c}} \\
3.13 \pm 0.12^{\mathrm{d}}\end{array}$ & $\begin{array}{l}2.30 \pm 0.22^{\mathrm{b}} \\
3.53 \pm 0.05^{\mathrm{c}} \\
3.53 \pm 0.05^{\mathrm{c}} \\
3.53 \pm 0.05^{\mathrm{c}}\end{array}$ \\
\hline
\end{tabular}

Different letters in the same column indicate the significant differences $(\mathrm{P}<0.05)$. 
chilled storage (Table 4). In case of samples coated at 0.5 and $1.0 \%$ moringa extract, TVB-N did not reach the value of 35 $\mathrm{mgN} 100 \mathrm{~g}^{-1}$, the data were curve fitted by fitting to the linear regression as response curve to the TVB-N data. Therefore, the shelf life for samples coated with 0.5 and $1.0 \%$ were predicted and could extended up to $16^{\text {th }}$ and $18^{\text {th }}$, respectively (Table 4 ). The shelf life using TVB-N value had an extended day compared to the bacteria indicators. However, with a great consideration on the safety, microbial should be the dominant to estimate the shelf life.

\section{Melanosis of Macrobranchium rosenbergii during iced storage}

Initially, there were no melanosis formation in all samples. However, after 15 days of chilled storage, controls were significantly $(\mathrm{P}<0.05)$ had an obvious melanosis formation compared to other treatments (Table 5). In contrast, $1.25 \%$ SMS were significantly $(\mathrm{P}<0.05)$ retard the melanosis formation in $M$. rosenbergii during 15 days of storage. $M$. rosenbergii coated with moringa extract had severe melanosis formation. Edmonds (2006) documented the inhibition of melanosis activity in $M$. rosenbergii treated with $1.25 \%$ SMS are due to the bleaching effects and undergone discolouration. Sulphite are most widely and effectively used to prevent melanosis in crustaceans (Bono et al., 2012; Lopez-Cabellero et al., 2006; Nirmal and Benjakul, 2009). Inhibition of browning involves nuclephilic attack by sulphite ion in position 4 of the o-quinone with catechol as substrate to give 4-sulfocatechol after subsequent addition of hydrogen ion. Therefore, the quinone has been reduced in the reaction (Kim et al., 2000). Melanosis inhibitory in $M$. rosenbergii that treated with moringa extracts is caused by the extraction technique that decreases the content of ascorbic acid and the irreversibly oxidation characteristic that oxidase ascorbic acid to dehydroascorbic acid during the reduction process, thus allowing browning to occur upon its depletion (Marshal et al., 2000).

\section{Sensory properties of $M$. rosenbergii during iced storage}

Initially, all samples were extremely liked by the panelist. After 15 days of storage, the taste, texture and odor of the controls were significantly $(\mathrm{P}<0.05)$ unacceptable. Interestingly, the taste of M. rosenbergii treated with moringa extracts were significantly $(\mathrm{P}<0.05)$ preferred compared to the $M$. rosenbergii treated with $1.25 \%$ SMS. However, the texture of M. rosenbergii treated with $1.25 \%$ SMS were similar
$(\mathrm{P}>0.05)$ even after 15 days of storage and significantly $(\mathrm{P}<0.05)$ desired compared to the $M$. rosenbergii treated with moringa extracts. But, there was no difference in odor likeness of $M$. rosenbergii treated with other treatments after 15 days of storage ( $\mathrm{P}>0.05$ ) (Table 5). Rotlant et al. (2002) stated the application of sulphites agents is to block the polyphenol oxidase activity and provide some partial bleaching to maintain an acceptable appearance. However, these are not necessary meet the flavor acceptance by the consumers. Loizzo et al., (2012) stated sulphite-containing inhibitor may causing off-flavors in the applied product.

\section{Conclusions}

Moringa extracts at $1.0 \%$ could effectively control the bacterial growth and chemical quality changes for $M$. rosenbergii stored in chilling temperature. The shelf-life were prolonged up to $9^{\text {th }}$ day. In addition, moringa extract also potentially to delay melanosis formation as it preserves the quality of the $M$. rosenbergii during iced storage. The common melanosis inhibitors, sodium metabisulphate has showed a better result inhibiting melanosis but leads to unacceptable taste to the consumers. Therefore, substitution of moringa extract are safe and potential in crustacean preservation agent.

\section{References}

Ali MY, Sharif MI, Adhikari RK, Faruque $\mathrm{O}, 2010$. Post mortem variation in total volatile base nitrogen and trimethylamine nitrogen between galda (Macrobrachium rosenbergii) and bagda (Penaeus monodon). Univ J Zool Rajshahi Unvi 28:7-10.

Anastasio A, Marrone R, Chirollo C, Smaldone G, Attouchi M, Adamo P, Sadok S, Pepe T, 2014. Swordfish steaks vacuum-packed with Rosmarinus officinalis. Ital J Food Sci 26:390-7.

Atawodi SE, Atawodi JC, Idakwo GA, Pfundstein B, Haubner R, Wurtele G, 2010. Evaluation of the polyphenol content and antioxidant properties of methanol extracts of the leaves, stem and root barks of Moringa oleifera Lam. J Med Food 13:710-6.

Benzie IF, Strain JJ, 1996. The ferric reducing ability of plasma (FRAP) as measurement of "antioxidant power" (Zingiberaceae): The FRAP assay. Anal Biochem 239:70-6.

Binsan W, Benjakul S, Visessanguan W,
Roytrakul S, Tanaka M, Kishimura H, 2008. Antioxidative activity of Mungoong, an extract paste, from the cephalothorax of white shrimp (Litopenaeus vannamei). Food Chem 106:185-93.

Bono $\mathrm{G}$, Badalucco CV, Cusumano S, Palmegiano GB, 2012. Toward shrimp without chemical additives: a combined freezing-MAP approach. LWT-Food Sci Technol 46: 274-9.

Chang CC, Yang MH, Wen HM, Chern JC, 2002. Estimation of total flavonoid content in propolis by two complementary colorimetric methods. J Food Drug Anal 10:178-82.

Chen M, Verdes RP, 2009. Elucidation of bactericidal effects incurred by Moringa oleifera and chitosan, JUS 4:65-79.

Cobb BF, Vanderzant C, 1975. Development of a chemical test for shrimp quality. J Food Sci 40:121-6.

Duman M, Öspolat E, 2015. Effects of water extract of propolis on fresh shibuta (Barbus grypus) fillets during chilled storage. Food Chem 189:80-5.

Edmonds M, 2006. Sodium metabisulphite alternatives. Seafish Technology Implementation. Technology Implementation Department, United Kingdom.

Fahey JW, 2005. Moringa oleifera: A review of the medical evidence for its nutritional, therapeutic and prophylactic properties. Trees Lif J 1:1-33.

Food and Agriculture Organization of the United Nations (FAO), 2014a. Macrobrachium rosenbergii. De Man, 1879. Available from: http://www.fao.org/fishery/culturedspecies/Macrobrachium_rosenbergii/en

Goncalves AA, Oliveira ARM, 2016. Melanosis in crustaceans; a review. LWT-Food Sci Technol 65:791-9.

Huss HH, 1995. Quality and quality changes in fresh fish, Rome: FAO Fisheries Technical Paper No. 348. Available from: http://www.fao. org/docrep/v7180e/v7180e00.htm\#Con tents

Ilyas M, Arshad MU, Saeed F, Iqbal M, 2015. Antioxidant potential and nutritional comparison of Moringa leaf and seed powders and their tea infusions. J Anim Plant Sci 25:226-33.

Iqbal S, Bhanger MI, 2006. Effect of season and production location on antioxidant activity of Moringa oleifera leaves grown in Pakistan. J Food Compos Anal 19:544-51.

Karim NU, Kennedy T, Linton M, Watson S, Gault N, 2011. Effect of high pressure processing on the quality of herring (Clupea harengus) and haddock 
(Melanogrammus aeglefinus) stored on ice. Food Control 22:476-84.

Khalafalla MM, Abdellatef E, Dafalla HM, Nassrallah AA, Aboul-Enein KM, Lightfoot DA, 2010. Active principle from Moringa oleifera Lam leaves effective against two leukemias and a hepatocarcinoma. Afr Journal Biotechnol 9:8467-71.

Kim J, Marshall, MR, Wei C, 2000. Polyphenoloxidase. In: Haard NF, Simpson BK, eds. Seafood enzymes: Utilization and influence on postharvest seafood quality. Marcel Dekker, New York, NY, pp 271-315

Kirschnik PG, Viegas EM, Valenti WC, de Oleivera CAF, 2006. Shelf life of the tail meat of the giant river prawn, Macrobrachium rosenbergii stored in Ice. J Aquat Food Prod T 15:57-71.

Lindner P, Angle S, Weinsberg ZG, Granit R, 1988. Factor inducing mushiness in stored prawns. Food Chem 29:119-32.

Linton M, Mc Clements JMJ, Patterson MF, 2003. Changes in the microbiological quality of shellfish, brought about by treatment with high hydrostatic pressure. Int Journal Food Sci Tech 8:71327.

Loizzo MR, Tundis R, Menichini F, 2012. Natural and synthetic tyrosinase inhibitors as anti-browning agents: an update. Institute of Food Technologists. Compr Rev Food Sci F, pp 11.

Madrid RMM, Phillips H, 2000. Post-harvest handling and processing. In: New MB, Valenti WC, eds. Freshwater prawn culture, the farming of Macrobrachium rosenbergii. Osney Mead, Oxford, UK, pp 326-44.

Makkar HPS, Becker K, 1996. Nutritive value and antinutritive components of whole and ethanol extracted Moringa oleifera leaves. Anim Feed Sci Tech 63:211-8.

Marshall MR, Kim J, Wei CI, 2000. Enzymatic browning in fruits, vegetables and seafoods. Available from: http://www.fao.org/ag/ags/agsi/ENZM EFINAL/Enzymatic\%20Browning.htm 1

Mogosanu GD, Grumezescu AM, Bejenaru C, Bejenaru LE, 2017. Natural products used for food production. Food Preserv 365-411.

New MB, Valenti WC, Tidwell J, D'Abramo LR, Kutty MN, 2010. Freshwater prawns: biology and farming. Blackwell Publishing Ltd, United Kingdom, UK, pp 407-8.

Nirmal NP, Benjakul S, 2009. Melanosis and quality changes of Pacific white shrimp (Litopenaeus vannamei) treated with catechin during iced storage. J Agric Food Chem 116:323-31.

Onyuka JHO, Kakai R, Arama PF, Ofulla AVO, 2013. Moringa oleifera plant extracts in fish from Lake Victoria basin of Kenya. Afr J Food Agric Nutr Dev 13:7772-88.

Palmieri G, Balestrieri M, Proroga YTR, Falcigno L, Facchiano A, Riccio A, Capuano F, Marrone R, Neglia G, Anastasio A, 2016. New antimicrobial peptides against foodborne pathogens: from in silico design to experimental evidence. Food Chem 211:546-54.

Peixoto JR, Silva GC, Costa RA, de Sousa Fontenelle JR, Vieira GH, Filho AA, dos Fernandes Vieira, RH, 2011. In vitro antibacterial effect of aqueous and ethanolic Moringa leaf extracts. Asian Pac J Trop Med 4:201-4.

Porwal V, Singh P, Gurjar D, 2012. A comprehensive study on different methods of extraction from guajava leaves for curing various health problem. Int J Eng Res Appl 2:490-6.

Ratshilivha N, Awouafack MD, Du Toit ES, Eloff JN, 2014. The variation in antimicrobial and antioxidant activities of acetone leaf extracts of 12 Moringa oleifera (Moringaceae) trees enables the selection of trees with additional uses. S Afr J Bot 92:59-64.

Reddy BS, Reddy KVS, 2014. Proximate composition of the fresh water prawn Macrobrachium rosenbergii in cultured and frozen stage from Nellore Coast, India. Int Food Res J 21:1707-10.

Rudrappa U, 2014. Moringa nutrition facts. Available from: http://www.nutritionand-you.com/moringa.html

Rotllant G, Arnau F, Garcia JA, Garcia N, Rodriguez M, Sarda F, 2002. Effect of metabisulphite treatments and freezing on melanosis inhibition in rose shrimp Aristeus antennatus (Risso, 1816). Food Sci Technol Int 8:243-7.

Saadabi AM, Abu ZAI, 2011. An in vitro antimicrobial activity of Moringa oleifera L. seed extracts against different groups of microorganisms. Aust J Basic and Appl Sci 5:129-34.

Siddhuraju P, Becker K, 2003. Antioxidant properties of various solvent extracts of total phenolic constituents from three different agro climatic origins of drumstick tree (Moringa oleifera Lam.) leaves. J Agric Food Chem 51:2144-55.

Taga MS, Miller EE, Pratt DE, 1984. Chia seeds as a source of natural lipid antioxidants. J Am Oil Chem Soc 61:928-31.

Viera GHF, Mourão JA, Ângelo ÂM, Costa RA, Vieira RHSDF, 2010. Antibacterial effect (in vitro) of Moringa oleifera and Annona muricata against Gram positive and Gram negative bacteria. Rev Inst Med Trop Sao Paulo 52:129-32. 